\title{
Safety and feasibility of the use of a bevacizumab-methylcellulose mixture as an adjunct to glaucoma surgery: a pilot study
}

\author{
Segurança e viabilidade do uso de uma mistura de bevacizumabe-metilcelulose como terapia adjuvante à \\ cirurgia anti-glaucomatosa: um estudo piloto
}

Jayter Silva Paula ${ }^{1}$, Danilo José Lopes Secches ${ }^{1}$, Marcelo Jordão Lopes Silva ${ }^{1}$, Maria de Lourdes Veronese Rodrigues ${ }^{1}$, Armando da Silva Cunha Junior ${ }^{2}$

\begin{abstract}
Bevacizumab, a monoclonal anti-vascular endothelial growth factor antibody, has been suggested as a potential healing therapeutic following glaucoma surgery. Here, we aimed to improve the bioavailability of bevacizumab when used as an adjunct therapy to non-penetrating deep sclerectomy (DS) by using a bevacizumab-methylcellulose mixture (BMM). Ten previously non-operated eyes in ten patients diagnosed with primary open angle glaucoma underwent DS with a subconjunctival injection of $0.3 \mathrm{ml}$ of BMM (bevacizumab $3.75 \mathrm{mg}$ incorporated into $4 \%$ methylcellulose) at the surgical site. Bevacizumab release was evaluated in vitro using size-exclusion high performance liquid chromatography (HPLC). Intraocular pressure (IOP), bleb morphology, corneal endothelial cell count (CECC), and complications were evaluated at 6 months after surgery. Using HPLC, bevacizumab was detected in BMM for up to $72 \mathrm{~h}$. Moreover, all surgical blebs remained expanded with hyaline material during the first week. A significant IOP reduction (mean $\pm S D=-10.3 \pm 5.4 \mathrm{mmHg}, P<0.001$ ) and diffuse blebs were observed at the final follow-up period. Although CECC was slightly reduced (-7.4\%), no complications were observed. In conclusion, bevacizumab was released from BMM, and the use of this innovative mixture yielded good results following DS with no complications. Further studies are required to determine its efficacy prior to establishing BMM as an adjunct treatment for penetrating and non-penetrating glaucoma surgeries.
\end{abstract}

Keywords: Trabeculectomy/adverse effects; Glaucoma/surgery; Sclerectomy; Antibodies, monoclonal, humanized/therapeutic use; Methylcellulose/therapeutic use; Mitomycin/therapeutic use; Chemotherapy, adjuvant; Intraocular pressure/ physiology

\section{RESUMO}

O bevacizumabe (um agente anti-fator de crescimento endotelial vascular) tem sido sugerido como potencial modulador cicatricial na cirurgia do glaucoma. Este estudo objetivou melhorar a biodisponibilidade do bevacizumabe, investigando a viabilidade de uma nova mistura de bevacizumabe-metilcelulose (BMM) como terapia adjuvante para a esclerectomia profunda não-penetrante (DS). Dez olhos sem cirurgias prévias de 10 pacientes com glaucoma primário de ângulo aberto foram submetidos à DS associada à uma injeção subconjuntival de 0,3 ml da mistura de bevacizumabe-metilcelulose (bevacizumabe 3,75 mg incorporado em metilcelulose 4\%) no sítio cirúrgico. A liberação de bevacizumabe foi avaliada in vitro através de cromatografia líquida de alta performance por exclusão de tamanho (HPLC). A pressão intraocular (PIO), a morfologia da ampola de filtração, a contagem de células endoteliais da córnea (CECC) e as complicações foram estudadas aos seis meses de sequimento. O bevacizumabefoi detectado a partir da mistura de bevacizumabe-metilcelulose por meio do HPLCaté 72 horas. Além disso, todas as ampolas cirúrgicas permaneceram expandidas com material hialino durante a primeira semana. Uma redução significativa da pressão intraocular (média $\pm D P=-10,3 \pm 5,4 \mathrm{mmHg}, P<0,001$ ) e ampolas difusas foram observadas ao final do período de seguimento. Embora a contagem de células endoteliais da córnea se mostrou discretamente diminuída $(-7,4 \%)$, nenhuma complicação foi observada. Nesteestudo, o bevacizumabe foi liberado da mistura de bevacizumabe-metilcelulose e o uso desta nova mistura se associou com bons resultados cirúrgicos e nenhuma complicação. Estudos futuros serão necessários para determinar sua eficácia, antes de se estabelecer a mistura de bevacizumabe-metilcelulose como um tratamento adjuvante às cirurgias penetrantes e não-penetrantes para o glaucoma.

Descritores: Trabeculectomia/efeitos adversos: Glaucoma/cirurgia: Esclerostomia Anticorpos monoclonais humanizados/uso terapêutico; Metilcelulose/uso terapêutico; Mitomicina/uso terapêutico; Quimioterapia adjuvante; Pressão intraocular/fisiologia

\section{INTRODUCTION}

Non-penetrating deep sclerectomy (DS) is a glaucoma surgery that aims to minimize the complications of trabeculectomy (TRAB), which often arise due to penetration of the anterior chamber. Nevertheless, excessive cicatrization of the surgical site may also limit the success rates of $D S^{(3)}$. The fibrosis of subconjunctival tissues is considered to be the leading cause of failure of glaucoma surgery. This problem is mitigated by using mitomycin C (MMC) and 5-fluorouracil
(5-FU) as adjunctive treatments ${ }^{(1)}$. However, complications frequently occur with these therapies, prompting investigation into alternative drugs for managing post-operative failure ${ }^{(1,2)}$.

Therapies that have been investigated in an attempt to minimize the adverse effects of using MMC and 5-FU include the administration of bevacizumab [monoclonal antibody directed to vascular endothelial growth factor (VEGF); Avastin ${ }^{\circledR}$ Genentech, San Francisco, California, USA ${ }^{(4)}$ and methylcellulose ${ }^{(5)}$ into the subconjunctival spa- 
ce. Bevacizumab may enhance the outcomes of glaucoma filtration surgery because VEGF is not only involved in angiogenesis but has been shown to display direct activity on fibroblast-related healing processes ${ }^{(6)}$. As a potential way to improve surgical success, prolonging the bioavailability of bevacizumab using slow delivery systems could result in improved outcomes compared with isolated bevacizumab eye injections. We have recently shown that using implants containing bevacizumab in an experimental glaucoma surgery is feasible, and has promising results ${ }^{(7)}$. Based on the promising findings of using bevacizumab and methylcellulose compounds in glaucoma surgery, we evaluated the safety and feasibility of a bevacizumab-methylcellulose mixture (BMM) as an adjunct therapy to DS.

\section{METHODS}

This prospective non-randomized interventional case series followed the principles outlined in the Declaration of Helsinki and was approved by the local Research Ethics Committee (process \# 5159/2009). Ten patients diagnosed with primary open-angle glaucoma (POAG) and indicated for glaucoma surgical treatment were included, and observed at the University Hospital of Ribeirão Preto Medical School.

The following diagnostic criteria were used to diagnose POAG: intraocular pressure (IOP) greater than $21 \mathrm{mmHg}$ irrespective of medical treatment, typical glaucomatous changes in the optic disc, and reliable visual field defects compatible with glaucoma in the achromatic perimetry.

All patients who underwent surgery met the following inclusion criteria: age between 18 and 80 years, POAG diagnosis, confirmed evidence of the progression of glaucoma damage, and two IOP measurements higher than the individualized target IOP. Patients were excluded if they had other forms of glaucoma, previous glaucoma filtration surgery, rubeosis iridis, other severe retinal or corneal diseases, well-known history of adverse effects to bevacizumab, or were pregnant or breast feeding women. All patients underwent typical DS, with stripping of the external wall of Schlemm's canal on the same day ${ }^{(7)}$. At the end of the surgery, the patients received a $0.3 \mathrm{~mL}$ subconjunctival injection of BMM (bevacizumab $3.75 \mathrm{mg}$ incorporated into 4\% methylcellulose) at the surgical site by the same surgeon (MJLS). BMM was prepared by ultracentrifugation $24 \mathrm{~h}$ prior to surgery, in a local compounding pharmacy.

In order to detect free bevacizumab, five $0.5 \mathrm{ml}$ samples of BMM were evaluated by size-exclusion high performance liquid chromatography (HPLC) using $50 \mu \mathrm{L}$ of BMM with a flow rate of $1.0 \mathrm{~mL} / \mathrm{min}$, at $72 \mathrm{~h}$ (Waters BioSuite 250, $5 \mu \mathrm{m}$, HR SEC $-7.8 \times 300 \mathrm{~mm}, \mathrm{pH} 7.4$, absorbance at $279 \mathrm{~nm})^{(8)}$. A HPLC column was used in which the mobile phase comprised PBS at a pH of 7.4. An ultraviolet detector (model 2487, Waters, USA) was used at a wavelength of $279 \mathrm{~nm}$, and the area under peak was used to determine the quantity of the drug in the test solution.

The following clinical outcomes were evaluated 6 months following surgery: IOP reduction (variation from pre- to post-operative average of three Goldmann tonometry readings taken between 08:00 h and 10:00 h), bleb's morphology (using the Moorfields bleb grading system) ${ }^{(9)}$, visual acuity (using charts with the logarithm of the minimum angle of resolution notations, logMAR), corneal endothelial cell count (CECC; using specular microscopy, ROBO NSP-9900, Konan, Japan), and complications. Data was presented as median with $25^{\text {th }}$ to $75^{\text {th }}$ interquartile range (IR) for scores, and mean with standard deviation (SD) for numerical data. The paired Friedman test was used to compare the results (Prism 5.0a; GraphPad Software Inc., CA, USA), and a p-value of $<0.05$ was defined as significant.

\section{RESULTS}

Ten caucasian patients (six males and four females, with a mean age of $56.4 \pm 12.7$ years) completed the procedure and 6 month follow-up. At the end of the follow-up, a significant IOP reduction was observed (20.7 $\pm 5.5 \mathrm{mmHg}$ pre-operative vs $10.4 \pm 2.5 \mathrm{mmHg}$ post-operative; $-10.3 \pm 5.4 \mathrm{mmHg}, \mathrm{P}<0.001$ ), and all patients exhibited diffuse blebs with low degrees of vascularity [median scores, with IR in parentheses - central area: 3.0 (3.0 to 3.75); maximal area: 3.5 (3.0 to 4.0); height: 2.0 (2.0 to 2.75); and vascularity: 2.0 (2.0 to 3.0)]. No significant difference was observed between the mean best-corrected pre-operative visual acuity score and that evaluated at the last visit ( $0.10 \pm 0.02$ and $0.15 \pm 0.03$, respectively). CECC was $7.4 \%$ lower 6 months after surgery ( $2529 \pm 464$ cells vs $2341 \pm 432$ cells, $\mathrm{P}=0.008)$. No complications were observed throughout the duration of the study.

HPLC detected bevacizumab in BMM at a mean retention time of $6.98 \mathrm{~min}$ across the five samples evaluated at $72 \mathrm{~h}$ (mean of $75.1 \%$ of free drug), close to the well-defined peak of free bevacizumab at 7.01 min (Figure 1) ${ }^{(5)}$ BMM could be observed in the bleb areas of all patients during the first week (Figure 2). The blebs remained expanded with the hyaline material, but the liquid interface of aqueous humor could not be visualized during the slit-lamp examination.

\section{DISCUSSION}

Here, we show that BMM is a safe, feasible system for the delivery of bevacizumab during the early post-operative period following DS. Our results suggest that bevacizumab is available at the surgical site for a longer period of time than that following simple subconjunctival
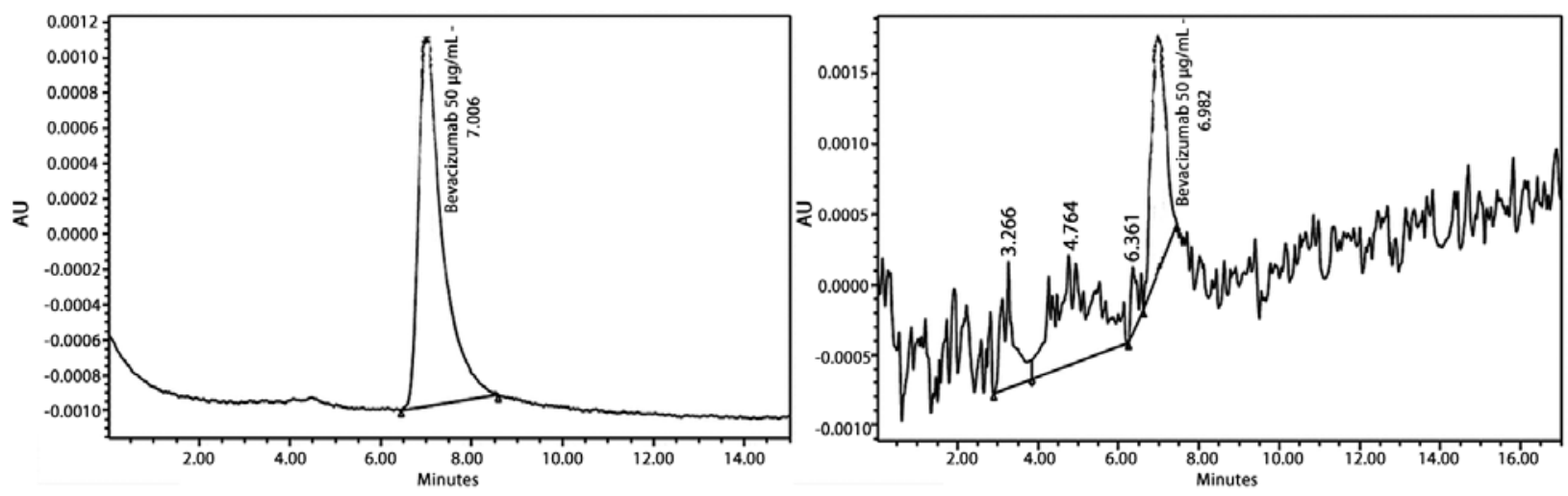

$\mathrm{AU}=$ Absorbance unit $(279 \mathrm{~nm}) \times 10^{4}$

Figure 1. Size-exclusion high performance liquid chromatograms of $50 \mu \mathrm{L}$ of bevacizumab (left) and one sample of BMM (right), at a flow rate of $1.0 \mathrm{~mL} / \mathrm{min}$ (Waters BioSuite $250,5 \mu \mathrm{m}, \mathrm{HR}$ SEC $-7.8 \times 300 \mathrm{~mm}, 72 \mathrm{~h}$ ). 


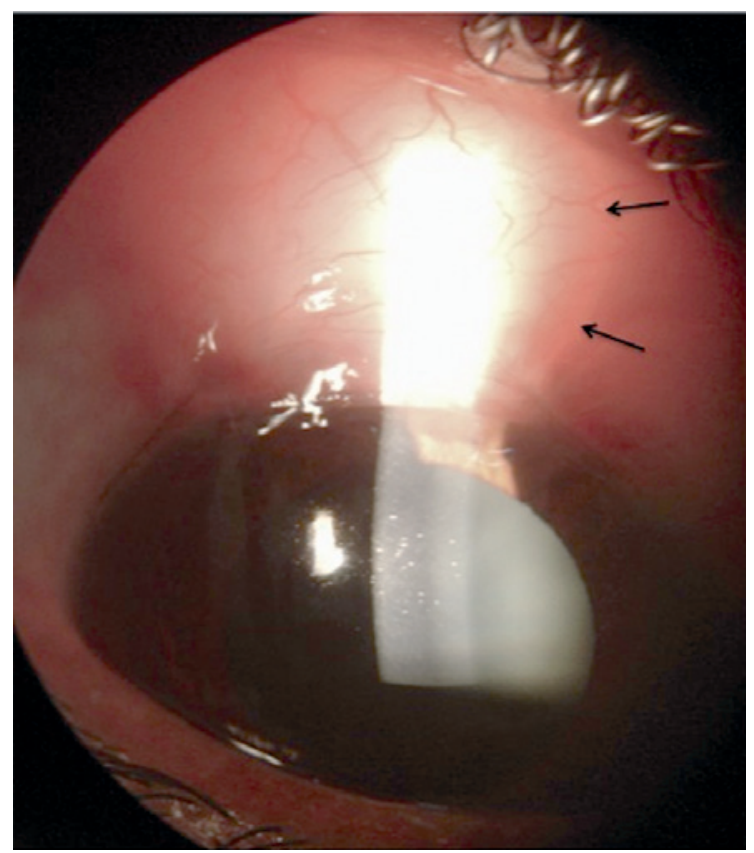

Figure 2. Slit-lamp photograph of the surgical site on the seventh day following deep sclerectomy augmented with BMM (patient \#5). Note the elevated bleb with the subconjunctival hyaline material (arrows).

injection of the antibody. Moreover, both bevacizumab and methylcellulose have previously shown benefits in terms of enhancing the healing process following glaucoma surgery ${ }^{(4,5)}$; thus, delivering both compounds may increase the therapeutic effect.

We could not determine whether there was a synergistic effect between bevacizumab and methylcellulose in this study, but we believe that BMM may act as a slow delivery system for bevacizumab to the subconjunctival space, particularly during the first week post-surgery. The artificial expansion of bleb volume with this viscoelastic product may also contribute additional benefits, primarily in the first phase of the healing process ${ }^{(7)}$.

Although CECC was significantly lower after surgery than before, this reduction was proportional to those reported in previous TRAB and DS studies ${ }^{(3,10)}$. We speculate that the non-penetrating procedu- re performed in our cases may help in limiting permeation of BMM into the anterior chamber, and may explain the reduction observed in CECC.

The limitations of this study, which include the absence of a control group, a small number of patients, and a short post-surgery evaluation period, should be addressed by future long-term follow-up randomized controlled trials. Moreover, use of BMM may result in higher costs related to the surgical procedure, and could add potential unforeseen complications related to both bevacizumab and methylcellulose administration. However, all patients enrolled in this study displayed good surgical results, and no complications were observed. Thus, efficacy and cost-effectiveness of BMM should be further verified prior to establishing it as an adjunctive therapy to DS, or other penetrating glaucoma surgeries.

\section{ACKNOWLEDGEMENT}

The authors would like to thank Elionai Cassiana de Lima Gomes for her help with performing the chromatograms.

\section{REFERENCES}

1. Mostafaei A. Augmenting trabeculectomy in glaucoma with subconjunctival mitomy cin C versus subconjunctival 5-fluorouracil: a randomized clinical trial. Clin Ophthalmol. 2011;5:491-4.

2. De Fendi LI, Arruda GV, Scott IU, Paula JS. Mitomycin C versus 5-fluorouracil as an adjunctive treatment for trabeculectomy: a meta-analysis of randomized clinical trials. Clin Experiment Ophthalmol. 2013:41(8):798-806.

3. Lüke C, Dietlein TS, Jacobi PC, Konen W, Krieglstein GK. A prospective randomized trial of viscocanalostomy versus trabeculectomy in open-angle glaucoma: a 1-year follow-up study. J Glaucoma. 2002;11(4):294-9.

4. Shouman AA, Helal A, Marzouk MA, Zaki EM. Methylcellulose, a healing inhibitor factor in an animal model of trabeculectomy. Invest Ophthalmol Vis Sci. 2006:47(6):2515-9.

5. Paula JS, Ribeiro VR, Chahud F, Cannellini R, Monteiro TC, Gomes EC, et al. Bevacizumab-loaded polyurethane subconjunctival implants: effects on experimental glaucoma filtration surgery. J Ocul Pharmacol Ther. 2013;29(6):566-73.

6. Li Z, Van Bergen T, Van de Veire S, Van de Vel I, Moreau H, Dewerchin M, et al. Inhibition of vascular endothelial growth factor reduces scar formation after glaucoma filtration surgery. Invest Ophthalmol Vis Sci. 2009:50(11):5217-25.

7. Roy S, Mermoud A. Deep sclerectomy. Dev Ophthalmol. 2012;50:29-36

8. Gomes EC, Cunha Junior AS, Yoshida Ml, Jorge R. Desenvolvimento e validação de método analítico para quantificação do fármaco bevacizumabe por cromatografia liquido de alta eficácia. Quim Nova. 2012;35(3):608-11.

9. Wells AP, Ashraff NN, Hall RC, Purdie G. Comparison of two clinical blebgrading sys tems. Ophthalmology. 2006:113(1):77-83.

10. Arnavielle S, Lafontaine PO, Bidot S, Creuzot-Garcher C, D'Athis P, Bron AM. Corneal endothelial cell changes after trabeculectomy and deep sclerectomy. J Glaucoma. 2007; 16(3):324-8 